Kelaniya Journal of Human Resource Management

Volume 11, Number 01 - January 2016

DOI: http://doi.org/10.4038/kjhrm.v11i1.24

\title{
Corporate Governance Determinants of Firm Performance: Empirical Evidence from Banking, Finance and Insurance Companies in Sri Lanka
}

\author{
K. M. Panditharathna \\ Department of Commerce and Financial Management, \\ University of Kelaniya, Sri Lanka
}

\begin{abstract}
This study examines the relationships between corporate governance attributes on firm performance of listed financial sector companies in Sri Lanka. Empirical analysis focused on 56 companies registered in the Colombo Stock Exchange (CSE) covering the industries of banking, finance and insurance for the years 2012, 2013, 2014 and 2015. The study used Ordinary Least Squares (OLS) method to analyze the data. The study finds that relationship between corporate governance and firm performance are not strong. Board size, proportion of independent directors and the proportion of female directors have not significant relationship with performance measures. But board effectiveness has a significant positive relationship with ROE. This study enables to companies to evaluate and restructuring of their board to enhance the performance of the company while contributing to the economic development of the country. Findings of prior study are more focused to the developed countries. This study fills that research gap and contribute to the present literature on corporate governance in the industries of banking finance and insurance.
\end{abstract}

Keywords: Board Structure, CSE, Corporate Governance, Firm Performance

\section{Introduction}

"Corporate governance involves set of relationship between a company's management, its board, and its shareholders. Corporate governance also provides the structure through which the objectives of the company are set, and the means of attaining those objectives and monitoring performance are determined". (OECD, 2015). The relationship between corporate governance 
and firm performance is broadly debated and well-researched areas in the developed countries. Despite the abundant academic research on corporate governance and firm performance where much attention is paid to the developed countries. (John et al., 2008; Mizuno, 2010; Eberhart, 2012) It is still in infancy in the context of developing countries like Sri Lanka. Additionally, these studies have used the agency theory to explain their empirical evidence (Eberhart, 2012). Corporate governance has been developed paying greater attention to the agency theory and it is based on the ground of shareholder value maximization (Li et al., 2013).

At the corporate point of view shareholders are the principals whereas managers are agents. Both owners and managers are utility maximizes management may not always act in order to maximize the owners' interest. Even though the aim of the corporation is to maximize the shareholder value, there is a possibility of agency conflicts. Corporate governance provides provisions and strategies to diminish the agency conflicts, as well as it ensures the shareholder value maximization. Equity prices and returns are a major matter in corporate finance. Therefore, identifying the relationship between corporate governance and firm performance is very important.

Grounded on agency theory main purpose of this paper is to examine the relationship between corporate governance and firm performance of companies which are registered in bank finance and insurance sector in CSE. Sri Lanka is a middle income developing country (World Bank, 2015). With the intention of direct and control the corporation's, corporate governance initiatives in Sri Lanka in 1997 and it has subsequently updated in 2003, 2008 and 2013. (The Institute of Chartered Accountants of Sri Lanka; Securities and Exchange Commission of Sri Lanka, 2013).

Study make several contributions to the literature. The first study to empirically test the relationship between corporate governance and firm performance based on 56 listed firms which are registered in CSE. Also study contribute to the literature about the connection between corporate governance and firm performance on Sri Lankan point of view because lots of studies have been made based on developed country context (Mizuno, 2010; Eberhart, 2012).

The paper is structured in the following way: second section presents the selected literature on the corporate governance, firm performance as well as 
agency theory. Third section presents data and methodology section number four covers empirical results and discussion. The conclusion limitations and future research are presented in the fifth section.

\section{Literature Review}

According to the (See; Jensen \& Meckling, 1976) agency relationship is a contract between principal(s) (Shareholders/Owners) and agent(s) (Managers). Owners appoint managers to perform services, giving decision making authority on behalf of owners. Separation ownership of a firm from owners to managers is cause to generate agency problems (Jensen \& Meckling, 1976; Fama \& Jensen, 1983). Managers are the persons who are affiliate daily operations of a firm. Therefore, managers are the persons who have invaluable information regarding firmer rather than owners who are discrete from the firm. Owners who are discrete from the firm cannot directly perceive their managers. This inconsistency of objectives in owners and managers are cause to arise agency problems. Managers pursuit their own benefits of the owners' capital (Sylvia et al., 2013). A firm which has a feebler corporate governance system have to face more agency conflicts and also managers who are working in such firms can take much more personal benefit (Core et al., 1999). Owners cannot accurately measure actual performance, of a firm due to asymmetry of information.

Several literature on corporate governance have been observed the relationship between corporate governance and firm performance. Some of them are state that the quality corporate governance system upgrade the firm performance (Brickley \& James, 1987; Weisbach, 1988; Rosenstein \& Wyatt, 1990; Byrd \& Hickman, 1992; Lee et al. 1992; Brickley et al.,1994; Hossain et al., 2000; Chung et al. 2003; Beiner et al., 2004; Brown \& Caylor, 2006; Black et al., 2006). On the other hand, some literature has stated that there is a negative relationship between corporate governance and firm performance (Bathala \& Rao, 1995; Hutchinson, 2002; Bauer, Guenster, \& Otten, 2004). Some other studies have reported no any positive or negative relationship between corporate governance and firm performance (Hermalin \& Weisbach, 1991; Park \& Shin, 2003; Prevost, Rao, \& Hossain, 2002; Singh \& Davidson, 2003; Young, 2003.) 
Gompers et al. (2003) Finds that firms which have strong shareholder rights also have high levels of firm performance, high profit and high sales growth by empirically examine the governance index with firm performance. Study done by (Klapper \& Love, 2002) based on the 14 developing countries corporate governance rank data find that strong corporate governance is positively influence to the operating profit and market value.

The above studies shows the relationship between corporate governance and firm performance But there is an unsold dilemma on how corporate governance relates to firm performance even though some studies have been done in this scenario (Sharma, 2016).

\section{Development of Hypotheses}

\subsection{Board size and Firm performance}

Existent literature provides two different aspects on board size. Those are large boards and small boards. Past literature stating that large boards are inefficient and no strong control on management as well as it is cause to increase agency cost. Furthermore, literature state that management influence is less in larger board while there is a high influence of management for small, efficient boards. (Luo, 2005; Laksmana, 2008; Said et al., 2009). Examine the influence of board size is an important factor on firm performance. Based on above indication below hypothesis is suggested:

H1: There is a positive association between board size and ROA

H2: There is a positive association between board size and ROE

\subsection{Board independence and Firm performance}

According to the principal of "Board balance" of the Code of best practice on corporate governance 2013, if composition of board directors includes only two non-executive directors, both of them should be 'Independent". On the other hand, if the board has more non-executive directors, one third of them should be "independent". (The Institute of Chartered Accountants of Sri Lanka; Securities and Exchange Commission of Sri Lanka, 2013). According to Jensen \& Meckling (1976) a firm can reduce the agency conflicts by increasing the independence directors on the board and agency theory suggest 
that it also leads to improve the monitoring quality. (Fama \& Jensen, 1983 ; Barako et al., 2006).

Previous studies have empirically analyzed the association between board independence and firm performance. If a firm has more non-executive directors that the board is more independence (John \& Senbet, 1998). Rosenstein \& Wyatt (1990) and Byrd \& Hickman (1992) argued that nonexecutive directors who act as independence directors can upgrade the firm performance. Opposing to this argument (see; Bhagat \& Bolton, 2002) described adverse relationship between board independence and firm performance. According to the above argument, It is hypothesized that:

H3: There is a positive association between Proportion of independent directors and ROA

H4: There is a positive association between Proportion of independent directors and ROE

\subsection{Proportion of female directors and Firm performance}

The proportion of female directors on the board is a contemporary topic in the recent corporate governance research. Female directors on the board are more efficient and active than the male directors, likely to have a positive influence to the company (Adams \& Ferreira, 2009). Liu et al., (2014) state that there are three or more female directors on the board, such board can boost the Firm performance rather than the companies which have fewer female directors on the board. Darko et al., (2016) Finds the positive relationship between the proportions of female directors on the board with firm performance. According to the study result of (Thrikawala et al., 2016) there is a negative relationship between the proportion of female directors on the board and firm performance. Supporting previous studies, test following hypothesis:

H5: There is a positive association between Proportion of female directors and ROA

H6: There is a positive association between Proportion of female directors and ROE. 


\subsection{Board effectiveness and firm performance}

The study measures the board effectiveness by the number of board meetings per annum. Prior researches argued that when boards meet frequently, such boards are likely to have more performance as well as they work harmoniously with shareholders. (Conger et al.,1998). But (Vafeas, 1999) state that board meetings not useful. Therefore study sought to investigate below hypothesis:

H7: There is a positive association between board effectiveness and ROA

H8: There is a positive association between board effectiveness and ROE

\subsection{Control Variables}

This study includes three firm specific characteristics as control variables. They are firm size, firm growth and leverage (Shamil et al., 2014), age. Firm size measured by Natural log of total assets (3 year average). Firm growth, the market value of shares/book value of equity. Leverage, measured through Long term debt/book value of equity. Age measures present year minus incorporate year.

\section{Methodology}

\subsection{Sample and Data}

62 companies listed on the Colombo Stock Exchange in the industries of Bank Finance and Insurance Sectors. Out of 62 registered companies 56 selected for the analysis provided the availability of annual reports for the four year period (2012 to 2015) in the CSE website. Therefore, there are 224 observations.

\subsection{Operationalization}

Independent variables of the study were board size, proportion of independent directors on the board, the proportion of female directors and board effectiveness. Dependent variables of study were Firm Performance (Measured through ROA and ROE)). Firm size, firm growth and firm 
Kelaniya Journal of Human Resource Management

Volume 11, Number 01 - January 2016

leverage used as a control variable. Operationalization of variable are presented in Table I.

Table I: Description of Variable used in the Study

\begin{tabular}{|c|c|c|c|}
\hline No & Variable & Indicator/s & Operational Definition \\
\hline \multicolumn{4}{|c|}{ Firm Performance Measures } \\
\hline 1. & ROA & Return on Asset & $\begin{array}{l}\text { Net profit after tax divided by total } \\
\text { asset }\end{array}$ \\
\hline 2. & ROE & Return on Equity & $\begin{array}{l}\text { Net profit after tax divided by total } \\
\text { equity }\end{array}$ \\
\hline \multicolumn{4}{|c|}{ Corporate Governance Variables } \\
\hline 3. & $\mathrm{BS}$ & Board Size & Number of directors \\
\hline 4. & PID & $\begin{array}{l}\text { Proportion of } \\
\text { Independent Directors }\end{array}$ & $\begin{array}{l}\text { Independent Directors/Total } \\
\text { Number of Directors }\end{array}$ \\
\hline 5. & PFD & $\begin{array}{l}\text { Proportion of Female } \\
\text { Directors }\end{array}$ & $\begin{array}{l}\text { Female Directors/Total Number of } \\
\text { Directors }\end{array}$ \\
\hline 6 & $\mathrm{BE}$ & Board Effectiveness & Number of meetings \\
\hline \multicolumn{4}{|c|}{ Control Variables } \\
\hline 6. & FS & Firm Size & $\begin{array}{l}\text { Natural log of total assets ( } 3 \text { year } \\
\text { average) }\end{array}$ \\
\hline 7. & FG & Firm Growth & $\begin{array}{l}\text { The market value of shares/book } \\
\text { value of equity }\end{array}$ \\
\hline 8. & FL & Leverage & $\begin{array}{l}\text { Long term debt/book value of } \\
\text { equity }\end{array}$ \\
\hline 9. & Age & Firm Age & Present year-incorporate year \\
\hline
\end{tabular}

\subsection{Methods of Data Analysis}

Ordinary least squares (OLS) model was used to analyze the data. To carry out the logistic regression, the control variables were entered and tested first and then independent variable were entered to perform full logistic regression analysis. The following models were used by study. 
Model I:

$\mathrm{Y}_{\mathrm{ROA}}=\alpha_{\mathrm{ROA}}+\beta \mathrm{fs}+\beta \mathrm{fg}+\beta \mathrm{lev}+\varepsilon_{\mathrm{ROA}}$

Model II:

$\mathrm{Y}_{\mathrm{ROA}}=\alpha_{\mathrm{ROA}}+\beta \mathrm{bs}+\beta \mathrm{pid}+\beta \mathrm{pfd}+\beta \mathrm{be}+\beta \mathrm{fs}+\beta \mathrm{fg}+\beta \mathrm{lev}+\varepsilon_{\mathrm{ROA}}$

\section{Model III:}

$\mathrm{Y}_{\mathrm{ROE}}=\propto_{\mathrm{ROE}}+\beta \mathrm{fs}+\beta \mathrm{fg}+\beta \mathrm{lev}+\varepsilon_{\mathrm{ROE}}$

Model IV:

$\mathrm{Y}_{\mathrm{ROE}}=\propto_{\mathrm{ROE}}+\beta \mathrm{bs}+\beta \mathrm{pid}+\beta \mathrm{pfd}+\beta \mathrm{be}+\beta \mathrm{fs}+\beta \mathrm{fg}+\beta \mathrm{lev}+\varepsilon_{\mathrm{ROE}}$

\section{Where;}

$$
\begin{aligned}
& \mathrm{Y}_{\mathrm{ROA}}=\text { Performance indicator ROA } \\
& \mathrm{Y}_{\mathrm{ROE}}=\text { Performance indicator ROE } \\
& \beta \mathrm{bs}=\text { Board Size } \\
& \beta \mathrm{pid}=\text { Proportion of Independent Directors } \\
& \beta \mathrm{pfd}=\text { Proportion of Female Directors } \\
& \beta \mathrm{be}=\text { Board Effectiveness } \\
& \beta \mathrm{fs}=\text { Firm Size } \\
& \beta \mathrm{fg}=\text { Firm Growth } \\
& \beta \text { lev }=\text { Leverage }
\end{aligned}
$$

\section{Result and Discussion}

\subsection{Descriptive Analysis}

Descriptive statistics of all variables are presented in Table II. Mean values of the Dependent variables are $0.0268,0.1683$ for ROA, ROE respectively. Mean Board size is 8.3094 and 0.4281 is mean of board independence, this indicates that proportion of independent directors represent only 42 per cent out of total directors of the sample. Mean values of female directors is 0.1231 this specifies that proportion of female directors only 12 per cent. Mean board effectiveness is 11.6995 . 
Table II: Descriptive Statistics

\begin{tabular}{|l|r|r|}
\hline \multicolumn{1}{|c|}{ Variable } & \multicolumn{1}{c|}{ Mean } & \multicolumn{1}{c|}{ S.D. } \\
\hline ROA & 0.0268 & 0.0257 \\
\hline ROE & 0.1683 & 0.2297 \\
\hline Board Size & 8.3094 & 2.4893 \\
\hline Prop. Independent Directors & 0.4281 & 0.1469 \\
\hline Prop. Female Directors & 0.1231 & 0.1101 \\
\hline Board effectiveness & 11.6995 & 3.9012 \\
\hline Firm Size & $64,658,431,509$ & $135,818,276,868$ \\
\hline Firm Growth & 1.8469 & 3.9105 \\
\hline Leverage & 5.3942 & 3.9358 \\
\hline Age & 27.5540 & 15.5221 \\
\hline
\end{tabular}

\subsection{Empirical Results}

In this segment, present the empirical results of the study on Corporate Governance variable on performance measures. As a first step, report the result of the impact of each dependent variable on the indicators of control variables of firm performance. In the second step report the impact of each corporate governance variables and performance indicators, along with the control variables.

Table III represents the results of analysis of performance measures (ROA and ROE).

According to the results of model I and model III there are no significant impact on growth and age with ROA and ROE. But results show a significant positive relationship between leverage and ROA and firm size with ROE in addition leverage significantly negatively relate to the ROE.

Aforesaid analysis indicates the absence of significant. Hence, researcher tested relationship with independent variables and control variables. The results (Table III- Model II) of the analysis shows that board size has a negative relationship with firm performance measures. Relationship with Board size and firm performance measures are not statistically significant at any significant level.

A study has hypothesized that board size has positive associations between Firm Performance. But empirical results show the insignificant negative 
relationship which is consistent with prior viewpoints of (Yermack, 1996). Therefore study reject $H 1$ and $H 2$.

Board independent is positively related to the Firm performance. But these relationships are insignificant. Based on the empirical results of the analysis researcher has to reject $H 3$ and $H 4$ since there are an insignificant positive relationship between board independence and performance measures. These results consistence with the previous findings of (Jackling \& Johl, 2009; Dwivedi \& Jain, 2005).

Conflicting to the expected proportion of female directors is negatively related with the ROA, ROE and also this relationship is not significant. Hence, the study has to reject $H 5$ and H.6. This is similar to the results of (Thrikawala et al., 2016).

Furthermore, contrary to the prospect, board effectiveness has a negative insignificant relationship with ROA. But empirical results show the significant positive relationship. Therefore study rejects $H 7$ according to the study done by Vafeas (1999) and accept $H 8$ as per the study of Conger, Finegold, \& Lawler III (1998).

\section{Table II: Empirical Results}

\begin{tabular}{|l|r|r|r|r|}
\hline \multirow{3}{*}{ Variable } & \multicolumn{2}{|c|}{ ROA } & \multicolumn{2}{c|}{ ROE } \\
\cline { 2 - 5 } & \multicolumn{1}{|c|}{ Model I } & \multicolumn{1}{c|}{ Model II } & \multicolumn{1}{c|}{ Model III } & \multicolumn{1}{c|}{ Model IV } \\
\hline Board size & - & -0.0003 & - & -0.00236 \\
\hline & - & -0.2700 & - & -0.2700 \\
\hline PID & - & 0.0261 & - & 0.2103 \\
\hline & - & 1.1900 & - & 1.5700 \\
\hline Pfd & - & -0.0252 & - & -0.0738 \\
\hline & - & -0.9600 & - & -0.4600 \\
\hline Be & - & -0.0004 & - & $0.0132 *$ \\
\hline & - & -0.5400 & - & 2.6100 \\
\hline Growth & 0.0004 & 0.0002 & -0.0031 & -0.0049 \\
\hline & 0.5900 & 0.3500 & -0.7100 & -1.1100 \\
\hline Firm size & -0.0013 & -0.0007 & $0.0554 * * *$ & $0.0577 * * *$ \\
\hline & -0.6100 & -0.3300 & 3.9900 & 3.9900 \\
\hline Leverage & $0.0014 *$ & $0.0014 *$ & $-0.0238^{*} * *$ & $-0.0247 * * *$ \\
\hline & 2.2600 & 2.21 & -6.1200 & -6.4000 \\
\hline Age & 0.0069 & 0.0072 & 0.0047 & -0.0231 \\
\hline & 1.5600 & 2.2100 & 0.1700 & -0.7900 \\
\hline
\end{tabular}


Kelaniya Journal of Human Resource Management Volume 11, Number 01 - January 2016

\begin{tabular}{|l|r|r|r|r|}
\hline Intercept & 0.0381 & 0.0241 & $-0.9940 * *$ & $1.1499 * * *$ \\
\hline & 0.7400 & 0.4700 & 3.2100 & 3.6800 \\
\hline R'squared & 0.0975 & 0.1097 & 0.1917 & 0.2301 \\
\hline Adj R`squared & 0.0596 & 0.0545 & 0.1577 & 0.1825 \\
\hline
\end{tabular}

Asterisks indicate significance at $10(*), 5(* *)$ and $1 \%(* * *)$

\section{Conclusion, Limitations and Directions for Future Research}

The study shows the relationship between corporate governance and firm performance of Sri Lankan companies listed on the Colombo Stock Exchange, representing the industries of Bank Finance and Insurance. The result of the study says that the relationship between corporate governance and firm performance is not very strong in Sri Lanka. The main findings of the study are; first, results show that board size, proportion of independent directors and the proportion of female directors have not significant relationship with performance measures. Second, board effectiveness has a significant positive relationship with ROE.

The finding of this study is an important implication to use to practice good corporate governance in developing countries like Sri Lanka. According to the theories through better corporate governance mechanism firms can reduce their agency cost. This implies that firms which are in the developing economics can improve their performance of the firm by adapting good corporate governance mechanism. However, according to the empirical results of the study find the not all corporate governance variables are significantly influenced to the performance of a firm.

Increasing in board size, independent directors and female directors are not reasons to enhance the performance of a firm. Significant positive relationship between board effectiveness and ROE implies that concept of board effectiveness is a new thought for the developing countries like Sri Lanka.

There are a number of corporate governance factors that influence the firm performance and all of them not used in the study. Future researchers can work on more variables such as Directors shareholdings their remuneration, board committees (audit, remuneration etc.), Institutional shareholdings to test the relationship between firm performance in developing country context. 
Few studies have test the impact of firm performance on board characteristics

(Garg, 2007). This inverse relationship also influence to the policy formulation and decision making. Future researchers can test this inverse relationship as well.

\section{References}

Adams, R. B., \& Ferreira, D. (2009). Women in the boardroom and their impact on governance and performance. Journal of Financial Economics, 291-309.

Asbaugh, H., Collins, D., \& LaFond, R. (2004). Corporate governance and the cost of equity Corporate governance and the cost of equity. Working paper.

Barako, D. G., Hancock, P., \& Izan, H. Y. (2006). Factors influencing voluntary corporate disclosures by Kenyan companies. Corporate Governance: An International Review, 107-125.

Bathala, C. T., \& Rao, R. P. (1995). The Determinants of Board Composition: An Agency Theory Perspective. Managerial and Decision Economics, 59-69.

Bauer, R., Guenster, N., \& Otten, R. (2004). Empirical Evidence on Corporate Governance in Europe. Journal of Asset Management, 91-104.

Bebchuk, L., Cohen, A., \& Ferrell, A. (2009). What matters in corporate governance? Review of Financial Studies, Vol. 22 No. 2, pp. 738-827.

Beiner, S., Drobetz, W., Schmid, M. M., \& Zimmerman, H. (2004). An integrated framework of corporate governance and firm valuation. European Financial Management, 249-283.

Beiner, S., Drobetz, W., Schmid, M., \& Zimmermann, H. (2006). An integrated framework of corporate governance and firm valuation. European Financial Management, 249-83.

Bhagat, S., \& Bolton, B. (2002). The non-correlation between board independence and long-term firm performance. Journal of Corporation Law, 231-274.

Black, B. S., Jang, H., \& Kim, W. (2006). Does Corporate Governance Predict Firms' Market Values? Evidence from Korea. Journal of Law, Economics and Organization, 366-413.

Bonazzi, L., \& Islam, S. M. (2007). Agency theory and corporate governance. Journal of Modelling in Management, Vol 2 ss 1 pp. 7 - 23. 
Kelaniya Journal of Human Resource Management Volume 11, Number 01 - January 2016

Brickley, J. A., \& James, C. M. (1987). The Takeover Market, Corporate Board composition and Ownership Structure:. Journal of Law and Economics, 161181.

Brickley, J. A., Coles, J. L., \& Terry, R. L. (1994). Outside directors and the adoption of poison pills. Journal of Financial Economics, 371-390.

Brown, L. D., \& Caylor, M. L. (2006). Corporate governance and firm valuation. Journal of Accounting and Public Policy, 409-434.

Byrd, J. W., \& Hickman, K. A. (1992). Do outside directors monitor managers: Evidence form Tender Offer Birds. Journal of Financial Economics, 195221.

Central Bank of Sri Lanka. (2008 August). SAARCFINANCE Governors' Symposiu "South Asia's Recent Growth and Future Prospects". Colombo: Central Bank of Sri Lanka.

Chung, K. H., Wright, P., \& Kedia, B. B. (2003). Corporate governance and market valuation of Capital and R\&D Investment. Review of Financial Economics, 161-172.

Conger, J., Finegold, D., \& Lawler III, E. (1998). Appraising boardroom performance. Harvard Business Review, 136-148.

Core, J. E., Holthausen, R. W., \& Larcker, D. F. (1999). Corporate governance, chief executive officer compensation and firm performance. Journal of Financial Economics, 51(3), 371-406.

Darko, J., Ali, Z., Godfrey, A., \& Uzonwanne, C. (2016). Corporate governance: the impact of director and board structure, ownership structure and corporate control on the performance of listed companies on the Ghana stock exchange. Corporate Governance, 16(2).

Durnev, A., \& Kim, E. (2005). To steal or not to steal: firm attributes, legal environment, and valuation. Journal of Finance, 1461-93.

Dwivedi, N., \& Jain, A. K. (2005). Corporate governance and performance of Indian firms: The effect of board size and ownership. Employee Responsibilities and Rights Journal, 161-172.

Eberhart, R. (2012). Corporate governance systems and firm value:1 evidence from Japan's natural experiment. Journal of Asia Business Studies, Vol. 6 Iss 2 pp. $176-196$. 
Kelaniya Journal of Human Resource Management

Volume 11, Number 01 - January 2016

Fama, E., \& Jensen, M. (1983). Separation of ownership and control. Journal of Law and Economics, 301-25.

Fosberg, R. H., \& Nelson, M. R. (1999). Leadership Structure and Firm

Performance. International Review of Financial Analysis, 375-93.

Garg, A. K. (2007). Influence of board size and independence on firm performance A study of Indian Companies. Vikalpa, Vikalpa.

Gompers, P., Ishii, L., \& Metrick, A. (2003). Corporate governance and equity prices. Quarterly Journal of Economics, 107-55.

Hermalin, B., \& Weisbach, M. (1991). The effects of board composition and direct incentives on firm performance. Financial Management, 101-112.

Hossain, M., Cahan, S. F., \& Adams, M. B. (2000). The Investment Opportunity Set and the Voluntary Use of Outside Directors: New Zealand Evidence. Accounting and Business Research, 263-273.

Hussainey, S. M. (2014). Corporate governance, analyst following and firm value. Corporate Governance, Vol.14 lss 4 pp. 453 - 466.

Hutchinson, M. (2002). An analysis of the association between firms' investment opportunities board composition and firm performance. Asia Pacific Journal of Accounting and Economics, 17-39.

Jackling, B., \& Johl, S. (2009). Board structure and firm performance: Evidence from India's top companies. Corporate Governance: An International Review, 92-509.

Jensen, M. C., \& Meckling, W. H. (1976). Theory of the firm: managerial behavior, agency costs and ownership structure. Journal of Financial Economics, Vol. 10 No. 5, pp. 703-728.

John, K., \& Senbet, L. W. (1998). Corporate governance and board effectiveness. Journal of Banking and Finance, 371-403.

John, K., Litov, U., \& Yeung, B. (August 2008). Corporate Governance and RiskTaki. The Journal of Finance, VOL. LXIII, NO.4.

Klapper, L., \& Love, I. (2002). Corporate governance, investor protection, and performance in emerging markets",. orld Bank Policy Research Working Paper No. 2818, World Bank, Washington, DC, April.

L, B., A, C., \& A, F. (2009). Whatmattersincorporategovernance? Review of Financial Studies, Vol. 22 No. 2, pp. 738-827. 
Kelaniya Journal of Human Resource Management Volume 11, Number 01 - January 2016

Laksmana, I. (2008). Corporate board governance and voluntary disclosure of executive compensation practices. Contemporary Accounting Research, 25 No. 4, 1147-1182.

Lee, C., Rosenstein, S., Rangan, N., \& Davidson III, W. N. (1992). Board composition and shareholder wealth:. Financial Management, 58-72.

Li, H., Jahera Jr, J. S., \& Yost, K. (2013). Corporate risk and corporate governance another view. Managerial Finance, Vol. 39 Iss 3 pp. 204 - 227.

Lipton, M., \& Lorsch, J. (1992). A modest proposal for improved corporate governance. The Business Lawyer, 59-77.

Liu, Y., Wei, Z., \& Xie, F. (2014). Do women directors improve firm performance in China? The Journal of Corporate Finance, 169-184.

Luo, Y. (2005). Corporate governance and accountability in multinational enterprises: concepts and agenda. Journal of International Management, 11, $1-18$.

Mizuno, M. (2010). Institutional investors, corporate governance and firm performance in japan. Pacific Economic Review, 653-665.

OECD. (2015). G20/OECD Principles of Corporate Governance. Thurkey.

Park, Y. W., \& Shin, H. H. (2003). Board composition and earning management in Canada. Journal of Corporate Finance, 1-27.

Prevost, A. K., Rao, R. P., \& Hossain, M. (2002). Determinants of board composition in New Zealand: A simultaneous equation approach. Journal of Empirical Finance, 373-397.

Rechner, P. L., \& Dalton, D. R. (1991). CEO Duality and Organizational Performance:A Longitudinal Analysis. Strategic Management Journal, 15560.

Rosenstein, S., \& Wyatt, J. G. (1990). Outside directors, board independence and shareholder wealth. Journal of Financial Economics, 175-191.

Rosenstein, S., \& Wyatt, J. G. (1990). Outside Directors, Board Independence and Shareholder Wealth. Journal of Financial Economics, 175-192.

Said, R., Zainuddin, Y. H., \& Haron, H. (2009). The relationship between corporate social responsibility disclosures and corporate governance characteristics in Malaysian public listed companies. Social Responsibility Journal, 5 No. 2, 212-226. 
Kelaniya Journal of Human Resource Management Volume 11, Number 01 - January 2016

Shamil, M. M., Shaikh, J. M., Ho, P.-L., \& Krishnan, A. (2014). The influence of board characteristics on sustainability reporting : Empirical evidence from Sri Lankan firms. Asian Review of Accounting, 78 - 97.

Sharma, A. A. (2016). Corporate Governance and Firm Performance in Developing Countries: Evidence from India", Corporate Governance. The International Journal of Business in Society, Vol. 16 Iss 2 pp.

Singh, M., \& Davidson, W. N. (2003). Agency cost, ownership structure and corporate governance mechanisms. Journal of Banking and Finance, 93816.

Sylvia, Siregar, V., Yan, \& Rahadian. (2013). Corporate governance,reporting quality, and firm value. Journal of Accounting in Emerging Economies, 420 .

The Institute of Chartered Accountants of Sri Lanka ; Securities ans Exchange Commission of Sri Lanka. (2008). Code of Best Practise on Corporate Governance. Colombo: The Institute of Chartered Accountants of Sri Lanka ; Securities ans Exchange Commission of Sri Lanka.

The Institute of Chartered Accountants of Sri Lanka; Securities and Exchange Commission of Sri Lanka. (2013). Code of Best Practise on Corporate Governance. Colombo: The Institute of Chartered Accountants of SriLanka ; Securities ans Exchange Commission of Sri Lanka.

Thrikawala, S., Locke, S., \& Reddy, K. (2016). Board structure-performance relationship in microfinance institutions' (MFIs) in an emerging economy. The International journal of Business in Society, 16.

Vafeas, N. (1999). Board meeting frequency and firm performance. Journal of Financial Economics, 113-142.

Weisbach, M. S. (1988). Outside directors and CEO turnover. Journal of Financial Economics, 432-460.

World Bank. (2015). World Development Indicators.

Yermack, D. (1996). Higher Market Values of Businesses with A Small Board of Directors. Journal of Financial Economics, 579-611.

Young, B. (2003). Corporate governance and firm performance: Is there a relationship? Ivey Business Journal Online, 1-4. 